\title{
Effect of Various Protein Sources on the Growth Rate and Feed Utilization by Females of White Leghorn Strains ${ }^{1,2}$
}

\author{
Manuel Soldevila, Juan A. Morassi, and Manuel Rojas-Daporta ${ }^{3}$
}

\begin{abstract}
Different combinations of soybean, tuna, and meat meals were evaluated using net gain and utilization of feed as criteria for comparison. Three studies were conducted, one during the starting and two during the growing periods using female chicks of the DeKalb strains. In all experiments the best combinations were those using zero or low percentages of meat meal with bone and tuna and soybean meals. A consistent decrease in overall performance resulted as the levels of meat meal with bone were increased in the diets. Levels of tuna fishmeal as high as $24 \%$ of the diets were satisfactory. In starting and growing diets for chicks of laying strains, the factor which may limit the use of tuna fishmeal is its cost compared to that of soybean meal or any other suitable substitute.
\end{abstract}

\section{INTRODUCTION}

Morassi et al. ${ }^{4}$ reported that if the protein supplement fraction of broiler diets was composed of equal parts of tuna fishmeal and soybean meal, good and satisfactory growth and utilization of feed resulted.

The objective of this study was to determine the best combinations of tuna fishmeal, soybean meal, and meat meal in diets for female chicks of White Leghorn strains during the starting and growing periods.

${ }^{1}$ Manuscript submitted to Editorial Board August 15, 1975.

${ }^{2}$ Data reported in study 2 are taken in part from a thesis submitted by the second author to the Graduate Faculty, College of Agricultural Sciences, University of Puerto Rico, Mayagüez, P.R., in partial fulfillment of the requirements for the degree of Master of Science.

${ }^{3}$ Associate Nutritionist, Animal Husbandry Department, Agricultural Experiment Station, University of Puerto Rico, Río Piedras, P.R.; former Graduate Student, Department of Animal Industries, Mayagüez Campus, University of Puerto Rico, with present address in Asunción, Paraguay, and former Animal Husbandman, Agricultural Experiment Station, University of Puerto Rico, Lajas, P.R., respectively.

${ }^{4}$ Morassi, J. A., Soldevila, M., and Rojas-Daporta, M., Effect of different combinations of tuna fishmeal, meat meal with bone, and soybean meal upon growth rate and utilization of feed by broilers in the starting and fattening periods, J. Agr. Univ. P.R. 54 (3): 541-50, 1970 . 


\section{MATERIALS AND METHODS}

Two feeding studies were conducted at the Lajas Substation and one at the Main Station in Río Piedras. The first one was conducted during the starting period (1 day to the 8th week of age), with seven combinations of tuna fish, soybean, and meat meals. A balanced incomplete block design with three replications was used. The experimental units consisted of 25 DeKalb chicks, housed in $3.64 \times 2.64 \mathrm{~m}$ floor pens. Heat was provided during the first 3 weeks. The diets were isocaloric.

The second study, conducted at Lajas during the growing period (8th to the 20th week of age), evaluated four combinations of soybean and

TABLE 1.-Composition of basal diets used in the different studies

\begin{tabular}{lccc}
\hline \multicolumn{1}{c}{ Ingredient } & $\begin{array}{c}\text { Starting- } \\
\text { study 1 }\end{array}$ & $\begin{array}{c}\text { Growing- } \\
\text { study 2 }\end{array}$ & $\begin{array}{c}\text { Growing- } \\
\text { study 3 }\end{array}$ \\
\hline Corn, dent no. 2, ground & $\%$ & $\%$ & $\%$ \\
Protein sources & 70.2 & 74.7 & 78.2 \\
Skim milk, dried & $26.0-29.4$ & 24.0 & 20.0 \\
Dicalcium phosphate & 2.0 & .0 & .0 \\
Limestone, ground & .5 & .5 & .5 \\
NaCl & .0 & .0 & .5 \\
Premix & .5 & .5 & .5 \\
Crude protein & $.3^{1}$ & $.3^{2}$ & $.3^{2}$ \\
Calcium & 15.59 & 15.09 & 15.05 \\
Phosphorus & 1.52 & 2.76 & 2.71 \\
\hline
\end{tabular}

${ }^{1}$ Contained 0.0006 vitamins $\mathrm{A}_{\mathrm{D}}(500,000 / 100,000 \mathrm{IU} / \mathrm{g}) ; 0.0004$ riboflavin; 0.0004 calcium pentothenate; 0.0016 niacin; 0.0250 manganese sulfate $(75 \%) ; 0.1000$ choline chloride (25\%); 0.0750 coccidiostat; 0.1200 terramycin $(7.5 \mathrm{~g}$ oxytetracycline and $5.5 \mathrm{mg}$ vitamin B $12 / \mathrm{kg})$.

${ }^{2}$ Contained 0.0006 vitamins $\mathrm{A} / \mathrm{D}_{3}(500,000 / 100,000 \mathrm{IU} / \mathrm{g}) ; 0.0002$ riboflavin; 0.0004 calcium pentothenate; 0.0008 niacin; 0.0250 manganese sulfate $(75 \%) ; 0.0750$ coccidiostat; 0.8500 terramycin (11.0 g oxytetracycline and $4.4 \mathrm{mg}$ vitamin B $12 / \mathrm{kg}$ ).

tuna fishmeals, using a complete block design with four replications. The experimental units consisted of 25 pullets, housed in floor pens $4.55 \times$ $4.55 \mathrm{~m}$.

In the third study, conducted at the Main Station during the growing period ( 7 th to 17 th week of age), seven combinations of soybean meal, tuna fishmeal, and meat meal with bone, and a commercial laying diet were evaluated, using a partially balanced incomplete block design with four replications. The experimental units consisted of 10 pullets, housed in floor pens $3.63 \times 1.82 \mathrm{~m}$.

Growth rate and feed utilization were used as criteria for comparison. Table 1 describes the basal diets used in the three studies. Feed and water were offered free choice. 


\section{RESULTS AND DISCUSSION}

The results of the first study are shown in table 2 . Chicks fed diets 3 and 4, containing a high level of meat meal, performed poorly.

The results of the second study are shown in table 3 . There were no statistical differences in either criterion compared even in diets containing $24 \%$ tuna fishmeal. Diet 1 had a P content of $1.19 \%$ compared to the recommended level of $0.6 \%$, but this did not cause any apparent adverse

TABLE 2-Average gain in weight and feed conversion for the starting study 1 , conducted at the Lajas Substation from February to April 1967

\begin{tabular}{crrrrrr}
\hline \multirow{2}{*}{ Diet } & \multicolumn{3}{c}{ Protein source } & Net gain & Feed conversion \\
\cline { 2 - 4 } & Soybean & Tuna & Meat & & \\
\hline No. & $\%$ & $\%$ & $\%$ & $L b$ & Lb feed/lb gain \\
7 & 8.9 & 13.3 & 4.4 & $1.45 \mathrm{a}^{1}$ & $2.80 \mathrm{a}$ \\
6 & 13.6 & 9.1 & 4.5 & $1.4 \mathrm{lb}$ & $2.87 \mathrm{a}$ \\
2 & 18.0 & 9.0 & .0 & $1.40 \mathrm{bc}$ & $2.90 \mathrm{a}$ \\
5 & 8.5 & 17.0 & .0 & $1.37 \mathrm{~cd}$ & $3.04 \mathrm{a}$ \\
1 & 13.0 & 13.0 & .0 & $1.35 \mathrm{~d}$ & $2.92 \mathrm{a}$ \\
3 & 19.6 & .0 & 9.8 & $1.27 \mathrm{e}$ & $2.86 \mathrm{a}$ \\
4 & .0 & 17.6 & 9.6 & 1.17 & $3.05 \mathrm{a}$ \\
\hline
\end{tabular}

${ }^{\prime}$ Means followed by the same letter or letters are not significantly different at the $\mathrm{P}=.05$ level.

TABLE 3.-Average growth and feed conversion for growing studies 2 and 3

\begin{tabular}{ccccccc}
\hline \multirow{2}{*}{ Diet } & \multicolumn{3}{c}{ Composition of protein sources } & Net gain & Feed conversion \\
\cline { 2 - 4 } & Soybean & Tuna & Meat & & \\
\hline No. & $\%$ & $\%$ & $\%$ & $L b$ & Lb feed/lb gain
\end{tabular}

Study 2-From 8 to 20 weeks old, conducted at the Lajas Substation from August to October 1965

$\begin{array}{rrrrrl}1 & 0 & 24 & 0 & 1.39 \mathrm{a}^{1} & 6.44 \mathrm{a} \\ 2 & 24 & 0 & 0 & 1.37 \mathrm{a} & 6.77 \mathrm{a} \\ 3 & 16 & 8 & 0 & 1.43 \mathrm{a} & 6.46 \mathrm{a} \\ 4 & 8 & 16 & 0 & 1.38 \mathrm{a} & 6.41 \mathrm{a}\end{array}$

Study 3-From 7 to 17 weeks old, conducted at the Main Station in Rto Piedras from July

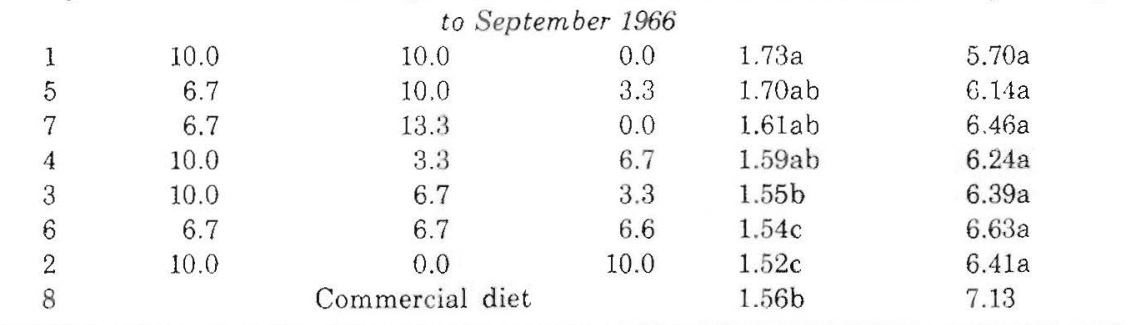

${ }^{1}$ Means followed hy the same letter or letters are not significantly different at the $\mathrm{P}=.05$ level. 
effects in either criterion compared, in contrast to reports at the same levels by Summers et al. ${ }^{5}$ and Twining et al. ${ }^{6}$

The results of feeding study 3 are shown in table 3 . The best combinations were those using 0 or the least amount of meat meal and containing about equal parts of soybean and tuna meals (diets 1 and 5). These results agree with those of Clark et al. ${ }^{7}$, Morassi et al. ${ }^{4}$, and the findings reported herein during the starting period.

\section{RESUMEN}

Se llevaron a cabo tres estudios, uno en el período inicial y dos en el periucio de crecimiento con pollitas y pollonas Liornas Blancas de la estirpe DeKalb. Se evaluaron diferentes combinaciones de harinas de soja, atún y carne, usando ganancia neta y utilización del alimento como criterios de comparación. En todos los estudios las mejores combinaciones fueron las de harinas de atún y de soja, con poca o ninguna harina de carne. Según aumentó el nivel de harina de carne en las dietas, bajó el crecimiento, y el alimento se utilizó en forma menos eficiente. Niveles de harina de atún tan altos como 24 por ciento de la dieta fueron satisfactorios. En dietas iniciales y de crecimiento para pollitas de estirpe ponedoras Liornas Blancas, el factor que quizás puede limitar el uso de la harina de atún, es su costo local cuando se compara con el de la harina de soja o cualquier otro sustituto apropiado.

${ }^{5}$ Summers, J. D., Slinger, S. J., and Ashton, G. C., Evaluation of meat meal as a protein supplement for the chick, Can. J. Anim. Sci. 44: 228-34, 1964.

${ }^{6}$ Twining, P. R., Lillie, R. J., Robel, E. J., and Denton, C. A., Calcium and phosphorus requirements of broiler chickens, Poultry Sci. 44: 283-96, 1965.

${ }^{7}$ Clark, T. B., Van Landingham, A. H., and Runnels, T. D., What protein for your battery chick ration?, W. Va. Agr. Exp. Sta. Bull. 298: 20-1, 1940. 